\title{
CLINICAL AND CYTOLOGICAL EVALUATION OF REMOVABLE PARTIAL DENTURE FABRICATED BY SELECTIVE LASER SINTERING ADDITIVE PROTOTYPING TECHNIQUE
}

\author{
Mohamed F Ahmed $B D S^{l}$, Faten S Abbas $P h D^{2}$, Samia S Omar $P h D^{3}$
}

\begin{abstract}
INTRODUCTION: Recent researches have shown that, in principle, computer-assisted design, computer-assisted manufacture and rapid prototype technologies (CAD/CAM/RP) can be successfully applied to the fabrication of removable partial denture (RPD) alloy frameworks and replace laboratory crafting techniques. The CAD/CAM techniques have been widely used for a long time to manufacture dental prostheses. Selective laser sintering (SLS), as an additive manufacturing (AM) method, is a new rapid prototyping technology which can be applied in the manufacturing of dental prosthesis based on layer-wise material addition.

OBJECTIVES: To evaluate the clinical efficiency of cobalt-chromium removable partial denture framework fabricated using CAD/Selective Laser Sintering technology clinically and cytologically.

MATERIALS AND METHODS: To carry out this study, six maxillary partially edentulous patients (class III modification 1. According to Kennedy classification) were selected from those attending the prosthodontics department, faculty of dentistry, Alexandria University. For each patient a cobalt chromium removable partial denture framework was fabricated using CAD/SLS technique then it was tried in and teeth were added, casted and inserted. Plaque index, gingival index, peridontal probing depth and clinical attachment level were evaluated and recorded for all patients at time of insertion, after 3 months and 6 months of follow up periods.

RESULTS: all removable partial dentures showed minimum plaque accumulation, no signs of gingival tissue inflammation, and no significance changes of periodontal probing depth and no significance of attachment loss of the peridontium.

CONCLUSION: all patients were satisfied with their dentures which fabricated by the computer aided design-computer aided manufacturing -rapid prototyping laser sintering technique (CAD/CAM/SLS) showing good oral environment response.

KEYWORDS: Removable partial denture, CAD-CAM/SLS, EOS system, Chrome-Cobalt SP2 powder, tissue response.
\end{abstract}

\footnotetext{
1. B.D.S. Prosthodontic Department, Faculty of dentistry, Alexandria University, Alexandria, Egypt

2. Professor of Prosthodontic, Faculty of dentistry, Alexandria University, Alexandria Egypt

3. Professor of oral Biology Department, Faculty of dentistry, Alexandria University, Alexandria Egypt
}

\section{INTRODUCTION}

The past decade has witnessed a growing interest in digital image technologies and model reproduction by electronic means. These technologies paved the way towards a significant advancement of the modeling and manufacture of dental replacements by introducing modern Computer Aided (CA) systems, state-of-the-art materials and machining technologies, as opposed to the conventional ways of manual manufacture which are prone to numerous subjective errors $(1,2)$.

In dentistry, CAD/CAM technologies have been applied in the field of prosthodontics ever since the 1980s. Nowadays these are also being extensively used in maxillofacial technology and surgery (3-5).

There has been a rapid increase in the employment of Computer-aided design (CAD) and Computer-aided manufacture (CAM) technologies in dental application instead of conventional RPD frameworks which are manufactured through what is called Lost Wax Technique avoiding errors of conventional technique (6-8).

The majority of currently used CAD/CAM systems are based on a milling procedure, where by requested forms, such as frameworks or full anatomical crowns, is fabricated by milling material from a block. (9, 10). Additive manufacturing (AM), on the other hand, uses a revolutionary layering additive technique, enabling the production of complex customized shapes such as , removable partial denture (RPD) frameworks (11).

Furthermore, Selective Laser Sintering (SLS) has been used in AM process to fabricate RPD frameworks in a single process. CAD utilize a 3D dimensional scan of patient's partially dentate mouth to replace oral impression, then multiple overlapping scans were used to collect point cloud data that were aligned using dedicated CAD software, then electronic surveying and the production of sacrificial pattern through a digital technologies have been achieved and, finally the RPD framework obtained in a direct metal sintering (DMLs) machine using the information from the generated 3D CAD site $(12,13)$.

The First step in clinical trials have been completed for using CAD/SLS dentures frameworks for accuracy, quality of fit and function: However, we need to know about long term effect of Removable Partial Denture frameworks which constructed by CAD/SLS on oral environment clinically and this was our aim.

\section{MATERIALS AND METHODS}

This study reviewed and accepted by committee of ethical scientific research,Faculty of dentistry, Alexandria University.

The clinical study was explained to the patients and they accept it.

This study was performed on six partially edentulous patients having bilateral maxillary partial edentulous class 111 (kennedy classification modification 1), Every individual received a chrome cobalt removable partial denture fabricated by computer aided designlselective laser sintering prototyping technique CAD/CAM/SLS. Patients were selected from the diagnostic clinic of Prosthodontics Department, faculty of Dentistry, Alexandria University. 
They were clinically evaluated at follow up periods at insertion, 3 months, and 6 months after.

The laser sintering machine and the cobalt chrome powder manufactured by EOS Ges.m.b.H. (FORMIGA P 100) Electro Optical System Ed. Klinger-Str. 12A-3423 St. Andrä-Wördern Austria ,Daniel Kopp , T +43 224233388 ,info@bibus.at /http://www.bibus.at.

The laboratory work was done by Hereaeus Modavest Investement from Heraeus Kulzer Heraeus, Dental Australia Pty Ltd Rydecorp_ Unit 6,2 Eden Park Drive Macquarie Park NSW Australia 2113, Phone: (02) 8422 6100,Fax:(02)98881460,Email:sales.mckulzer@heraeus.co m, Website: www.haraeus-dental.com

The Removable partial dentures were fabricated as follows:-

Designing the frameworks: Preliminary impression was recorded for each patient using irreversible hydrocolloid impression material (Cavex CA37 (normal set), hollandBV, Haarlem) .Then it was poured to get study cast .A custom tray was fabricated using auto polymerized acrylic resin material. Each study cast was scanned using digital dental scanner (3 shape D900 digital scanner3shape) to get a preliminary virtual model and indicate the proposed mouth preparations (Figure. 1)

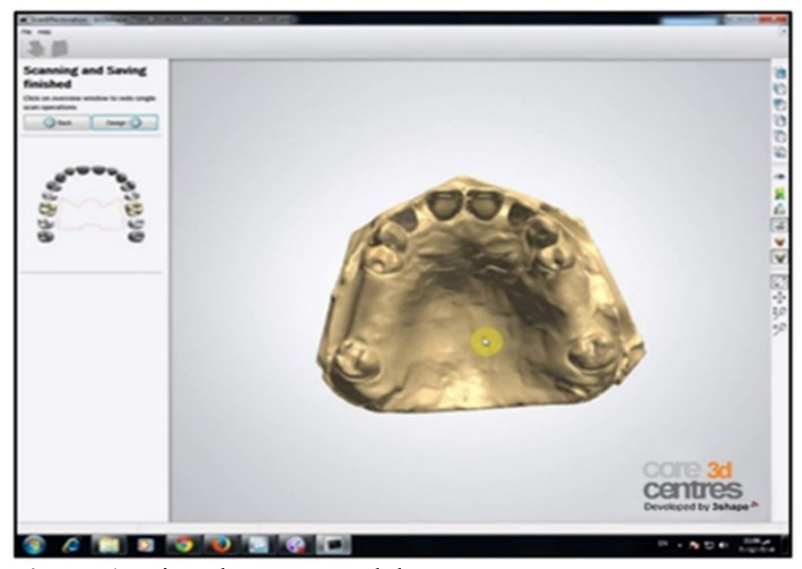

Figure 1: Virtual master model

Suggested mouth preparation chart was filled and an essential mouth preparation was done according to the suggested design which included: Aker clasps for both premolar and molar abutments. Distal rest seats for the premolar abutments and mesial rest seats for molar abutment, Palatal strap major connector, and Proximal guiding plans at the proximal surfaces next to the saddle.

A final impression was recorded using auto polymerized acrylic custom tray with a medium body Monophase additive poly vinyl siloxane impression material (Zhermac SPA via bovazecchino, 10045021 Badia polesine (RO) ITALY).

This final impression was poured in fast set extra hard type IV dental stone (Kimberlit, protechno, ginora, spain) to get the master cast which was scanned using digital scanner to produce a virtual 3D master model showed on the computer screen.

Restoration type was normally selected on the restorations chart as a removable partial denture. By using auto survey function through $\mathrm{CAD} \backslash \mathrm{CAM}$ software,the location and extent of undercuts were easily viewed on the scan and the clasp design was also determined and shaped. (Figure.2)

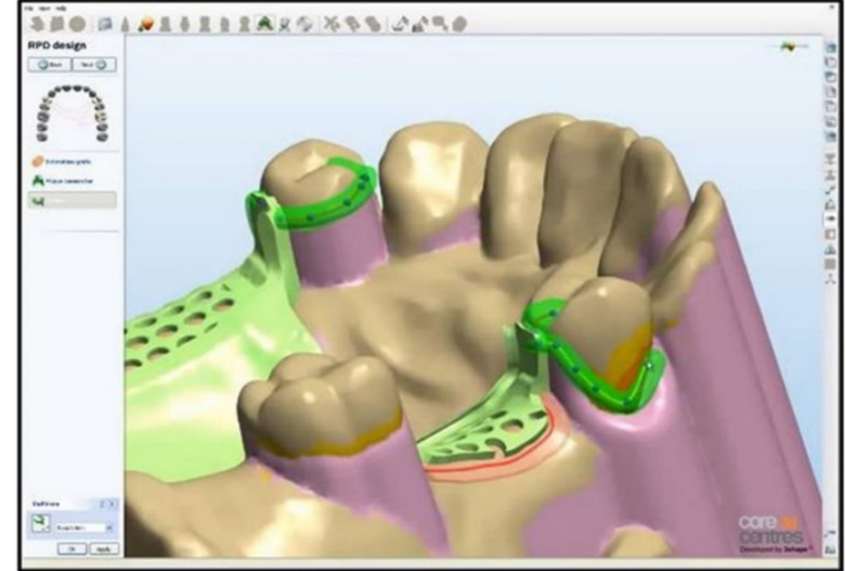

Figure 2: Clasp design.

The framework mesh styles and holes were also shaped and adjusted through the provided software.

For our study the major connector was selected to be palatal strap.

After finishing the major connector, the minor connector and rest components were drawn.

Proper clasp placement were ensured to engage the proper amount of undercut to be appropriate retentive, for our study Aker clasps were selected for molar and premolar abutments with a design made by selecting the best site of the undercuts. This was achieved by viewing a color gradient provided in the design software that showed how much undercut was present on the tooth.

There was a smoothing tool that allowed removing any sharp angles or rough areas that were inadvertently created during the design phase. Next, the finish lines were added. When the design was completed, tissue stops and support bars were added to the virtual pattern. (Figure.3)

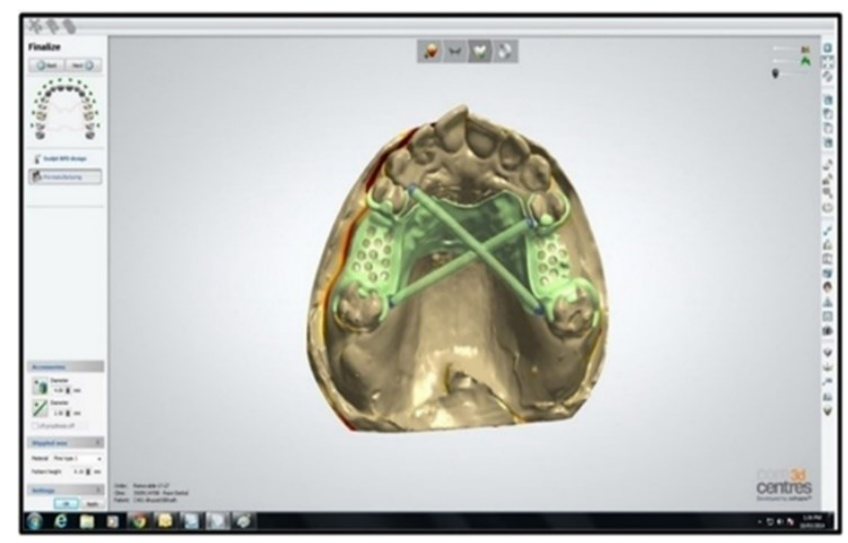

Figure 3: Tissue stops and support bars.

Once the RPD design was completed, it was exported to the machine in the form of STL (Standard tessellation language) file through slicing the $3 \mathrm{D} \mathrm{CAD}$ file data into layers. STL technology is commonly used in transferring $\mathrm{CAD}$ models to rapid prototyping (RP) technologies.

Technical procedure of the designed framework: The powder was spreaded by a roller over the surface of a build cylinder. The piston in the cylinder was moved down one object layer thickness to accommodate the new layer of powder. Piston was moved upward incrementally to supply a measured quantity of powder for each layer. Then the laser beam scans over a thin layer of powder previously deposited on the build tray and leveled with a roller. The laser beam 
heats localized area of the powder particles and fuse them to form a layer of object.

The fabrication chamber was maintained at a temperature just below the melting point of the powder so that the laser elevated the temperature slightly to cause sintering; the process was repeated layer by layer, until the entire object was formed. The typical layer thickness for this technique was (from 0.02 to $0.06 \mathrm{~mm}$ )

The sintered metallic frameworks were being required just minimal finishing and polishing to the external surface only.

Each metal framework of the removable partial denture was tried intraorally. (Figure.4)

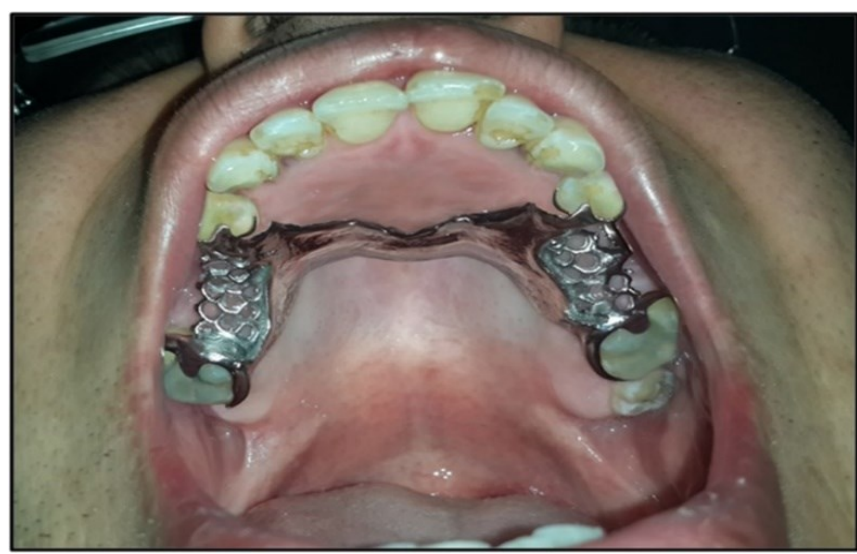

Figure 4: Intra oral try in.

The maxillary record block was done and placed in patients' mouth for jaw relation procedure in which centric, lateral and protrusive movements were registered then mounted on whipmix articulator using ear-piece face bow transfer.

The suitable acrylic teeth were selected, arranged, and tried in patient mouth. Insertion was done and patients were instructed for the proper oral hygiene measures (Figure.5).

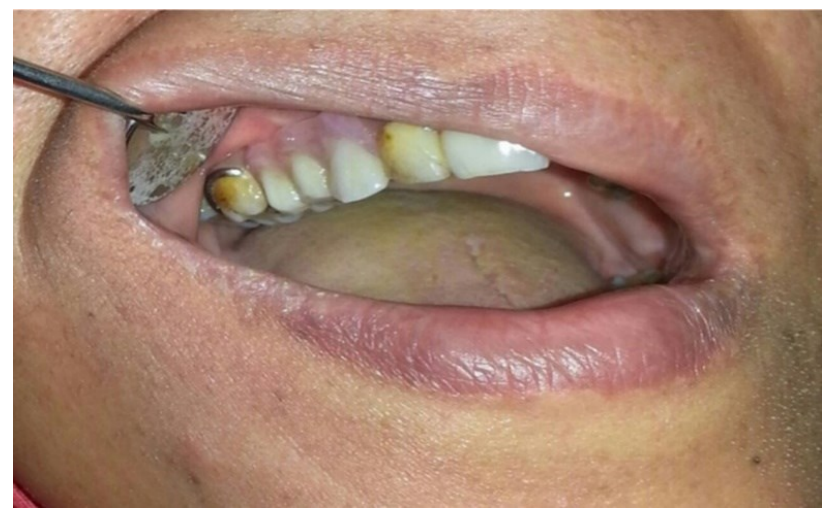

Figure 5: RPD insertion.

\section{METHODS OF EVALUATION}

All the six patients were clinically and cytologically at three different observation period (at time of insertion and 3 and 6 month of denture use).

The intraoral evaluation parameters included:-

\footnotetext{
A) CLINICAL EVALUATION:

1- Plaque index (PI) (14).

2- Gingival index (GI) (15).

3- Periodontal probing depth (PPD) (16).

4- Clinical attachment level (16).
}

\section{B) Cytological examination (17).}

C) Statistical analysis (18)

The data were collected by clinical surveys, tabulated and statistically analyzed. Mean standard deviation and median. The distributions of quantitative variables were tested for normality using Kolmogorov-Smirnov test, Shapiro-Wilk test and D'Agstino test.

\section{RESULTS \\ A) CLINICAL RESULTS:}

1- Plaque index (PI): (Table 1) Showed the evaluation of Plaque index at all follows up periods of denture use.

2- Gingival index (GI): Generally there were no signs of inflammation or bleeding of the gingival of all the studied abutment teeth. Gingival index scores were (0) for all abutments teeth during the six months period of denture use.

3- Peridontal probing depth (PPD): (Table 2) showed the evaluation of Peridontal probing depth at all follows up periods.

4- Clinical attachment level (CAL): (Table 3) Showed evaluation of clinical attachment level at all follows up periods.

B) Cytological results: Histological examination of the smears obtained from the different patients at the three different observation periods revealed the absence of any type of inflammatory cells among the epithelial cells desquamated in the swabs. During the first observation period the predominating epithelial type in the smear was that of the precornified variety, then changed to be a mix of both precornified and cornified type in the second observation period while complete change to (cornified) orthokeratinization was the dominant type observed in the third study period. (Figure 6A-C)


Figure 6A-C: Light microscopes of cytological smears of the oral epithelium in the swabs obtained at time of denture wearing (A), 3 months after denture wearing (B), and 6 months (C) after denture wearing. Papanicolaou stain, Ax 100\& B, C x 400. Arrows in (B) are pointed to the precornified cells.

\section{DISCUSSION}

This study was conducted to evaluate clinically and cytologically the response of the periodontal and gingival tissue to wearing partial denture fabricated by laser sintering rapid prototyping technique (CAD/SLS) and the effect of the denture on plaque accumulation, gingival response, and periodontal condition of the abutments teeth.

For this purpose, six partially edentulous patients were selected with maxillary class III kennedy classification modification 1 and indicated for palatal strap major connector 
Table (1): Comparison of the plaque index of the studied abutment teeth between the follow up periods:

\begin{tabular}{|c|c|c|c|c|}
\hline & Plaque index (Mean) & $\begin{array}{l}\text { First reading during insertion } \\
(\mathrm{n}=6)\end{array}$ & $\begin{array}{l}\text { Second reading } \\
\text { after } 3 \text { months } \\
(\mathrm{n}=6)\end{array}$ & $\begin{array}{l}\text { Third reading } \\
\text { after } 6 \text { months } \\
(\mathrm{n}=6)\end{array}$ \\
\hline \multirow{10}{*}{ 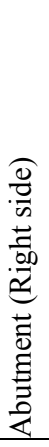 } & Mesial to the saddle (No.1) & & & \\
\hline & Min. - Max. & $0.0-0.0$ & $0.25-0.50$ & $0.25-0.75$ \\
\hline & Mean \pm SD & $0.0 \pm 0.0$ & $0.29 \pm 0.10$ & $0.50 \pm 0.16$ \\
\hline & Median & 0.0 & 0.25 & 0.50 \\
\hline & Sig. bet. periods & \multicolumn{3}{|c|}{$\mathrm{p}_{1}=0.020^{*}, \mathrm{p}_{2}=0.024^{*}, \mathrm{p}_{3}=0.025^{*}$} \\
\hline & Distal to the saddle (No.2) & & & \\
\hline & Min. - Max. & $0.0-0.0$ & $0.25-0.50$ & $0.25-0.75$ \\
\hline & Mean $\pm \mathrm{SD}$ & $0.0 \pm 0.0$ & $0.29 \pm 0.10$ & $0.50 \pm 0.16$ \\
\hline & Median & 0.0 & 0.25 & 0.50 \\
\hline & Sig. bet. periods & \multicolumn{3}{|c|}{$\mathrm{p}_{1}=0.020^{*}, \mathrm{p}_{2}=0.024^{*}, \mathrm{p}_{3}=0.025^{*}$} \\
\hline \multirow{10}{*}{ 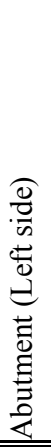 } & Mesial to the saddle (No.3) & & & \\
\hline & Min. - Max. & $0.0-0.0$ & $0.25-0.50$ & $0.50-0.50$ \\
\hline & Mean \pm SD. & $0.0 \pm 0.0$ & $0.29 \pm 0.10$ & $0.50 \pm 0.0$ \\
\hline & Median & 0.0 & 0.25 & 0.50 \\
\hline & Sig. bet. periods & \multicolumn{3}{|c|}{$\mathrm{p}_{1}=0.020^{*}, \mathrm{p}_{2}=0.014^{*}, \mathrm{p}_{3}=0.025^{*}$} \\
\hline & Distal to the saddle (No.4) & & & \\
\hline & Min. - Max. & $0.0-0.0$ & $0.25-0.25$ & $0.25-1.0$ \\
\hline & Mean $\pm \mathrm{SD}$ & $0.0 \pm 0.0$ & $0.25 \pm 0.0$ & $0.46 \pm 0.29$ \\
\hline & Median & 0.0 & 0.25 & 0.38 \\
\hline & Sig. bet. periods & \multicolumn{3}{|c|}{$\mathrm{p}_{1}=0.014^{*}, \mathrm{p}_{2}=0.026^{*}, \mathrm{p}_{3}=0.102$} \\
\hline
\end{tabular}

$\mathrm{p}_{1}$ : $\mathrm{p}$ value for Wilcoxon signed ranks test for comparing between First reading and second reading $\mathrm{p}_{2}$ : $\mathrm{p}$ value for Wilcoxon signed ranks test for comparing between First reading and third reading $\mathrm{p}_{3}$ : $\mathrm{p}$ value for Wilcoxon signed ranks test for comparing between second reading and third reading

*: Statistically significant at $\mathrm{p} \leq 0.05$

Table (2): Comparison of the periodontal probing depth between the different studied follow up periods

\begin{tabular}{|c|c|c|c|c|c|}
\hline & Pocket depth (Mean) & \begin{tabular}{|lll} 
First & reading & during \\
$(\mathrm{n}=6)$ & & \\
\end{tabular} & insertion $\mid \begin{array}{ll} & \begin{array}{l}\text { econd } \\
\text { after } \\
(n=6)\end{array} \\
\end{array}$ & 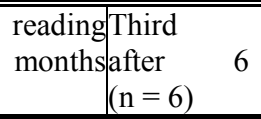 & \begin{tabular}{l|} 
reading \\
months
\end{tabular} \\
\hline \multirow{4}{*}{ 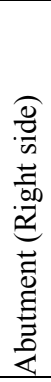 } & $\begin{array}{l}\text { Mesial to the saddle } \\
\text { Min. - Max. } \\
\text { Mean } \pm \text { SD. } \\
\text { Median }\end{array}$ & $\begin{array}{l}1.25-1.75 \\
1.54 \pm 0.19 \\
1.50\end{array}$ & $\begin{array}{l}1.50-1.75 \\
1.54 \pm 0.10 \\
1.50\end{array}$ & $\begin{array}{l}1.50-2.0 \\
1.71 \pm 0.19 \\
1.75\end{array}$ & \\
\hline & Sig. bet. periods & \multicolumn{4}{|l|}{$\mathrm{p}_{1}=1.000, \mathrm{p}_{2}=0.102 \mathrm{p}_{3}=0.175$} \\
\hline & $\begin{array}{l}\text { Distal to the saddle } \\
\text { Min. - Max. } \\
\text { Mean } \pm \text { SD. } \\
\text { Median }\end{array}$ & $\begin{array}{l}1.25-1.75 \\
1.42 \pm 0.20 \\
1.38\end{array}$ & $\begin{array}{l}1.50-2.0 \\
1.63 \pm 0.21 \\
1.50\end{array}$ & $\begin{array}{l}1.75-2.0 \\
1.83 \pm 0.13 \\
1.75\end{array}$ & \\
\hline & Sig. bet. periods & \multicolumn{4}{|l|}{ 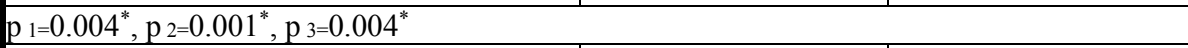 } \\
\hline \multirow{4}{*}{ 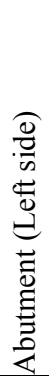 } & $\begin{array}{l}\text { Mesial to the saddle } \\
\text { Min. - Max. } \\
\text { Mean } \pm \text { SD. } \\
\text { Median }\end{array}$ & $\begin{array}{l}1.50-1.75 \\
1.63 \pm 0.14 \\
1.63\end{array}$ & $\begin{array}{l}1.50-2.0 \\
1.75 \pm 0.16 \\
1.75\end{array}$ & $\begin{array}{l}1.50-2.0 \\
1.75 \pm 0.16 \\
1.75\end{array}$ & \\
\hline & Sig. bet. periods & \multicolumn{4}{|l|}{$\mathrm{p}_{1=0.203, \mathrm{p}_{2}=0.076, \mathrm{p}_{3}=1.000}$} \\
\hline & $\begin{array}{l}\text { Distal to the saddle } \\
\text { Min. - Max. } \\
\text { Mean } \pm \text { SD. } \\
\text { Median } \\
\end{array}$ & $\begin{array}{l}1.25-1.75 \\
1.58 \pm 0.20 \\
1.63\end{array}$ & $\begin{array}{l}1.50-2.0 \\
1.79 \pm 0.19 \\
1.75\end{array}$ & $\begin{array}{l}1.75-2.0 \\
1.92 \pm 0.13 \\
2.0\end{array}$ & \\
\hline & Sig. bet. periods & \multicolumn{4}{|l|}{$\mathrm{p}_{1}=0.004^{*}, \mathrm{p}_{2}=0.010^{*}, \mathrm{p}_{3}=0.076$} \\
\hline
\end{tabular}

p1: Stands for adjusted Bonferroni p-value for ANOVA with repeated measures for comparison between $1^{\text {st }}$ and $2^{\text {nd }}$ reading $\mathrm{p}_{2}$ : Stands for adjusted Bonferroni p-value for ANOVA with repeated measures for comparison between $1^{\text {st }}$ and $3^{\text {rd }}$ reading $\mathrm{p}_{2}$ : Stands for adjusted Bonferroni $\mathrm{p}$-value for ANOVA with repeated measures for comparison between $2^{\text {nd }}$ and $3^{\text {rd }}$ reading

*: Statistically significant at $\mathrm{p} \leq 0.05$ 
Table (3): Comparison of the clinical attachment level of all abutment teeth between the different studied follow up periods.

\begin{tabular}{|c|c|c|c|c|}
\hline & Clinical attachment level (Mean) & $\begin{array}{l}\text { First reading during insertion } \\
(\mathrm{n}=6)\end{array}$ & $\begin{array}{l}\text { Second reading } \\
\text { after } 3 \text { months } \\
(\mathrm{n}=6)\end{array}$ & $\begin{array}{l}\text { Third reading } \\
\text { after } 6 \text { months } \\
(\mathrm{n}=6)\end{array}$ \\
\hline \multirow{4}{*}{ 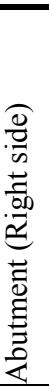 } & $\begin{array}{l}\text { Mesial to the saddle (No.1) } \\
\text { Min. - Max. } \\
\text { Mean } \pm \text { SD. } \\
\text { Median }\end{array}$ & $\begin{array}{l}0.25-0.75 \\
0.54 \pm 0.19 \\
0.50\end{array}$ & $\begin{array}{l}0.50-0.75 \\
0.54 \pm 0.10 \\
0.50\end{array}$ & $\begin{array}{l}0.50-1.0 \\
0.71 \pm 0.19 \\
0.75\end{array}$ \\
\hline & Sig. bet. periods & \multicolumn{3}{|l|}{$\mathrm{p}_{1}=1.000, \mathrm{p}_{2}=0.102, \mathrm{p}_{3}=0.157$} \\
\hline & $\begin{array}{l}\text { Distal to the saddle (No.2) } \\
\text { Min. - Max. } \\
\text { Mean } \pm \text { SD. } \\
\text { Median }\end{array}$ & $\begin{array}{l}0.25-0.75 \\
0.42 \pm 0.20 \\
0.38\end{array}$ & $\begin{array}{l}0.50-1.0 \\
0.63 \pm 0.21 \\
0.50\end{array}$ & $\begin{array}{l}0.75-1.0 \\
0.83 \pm 0.13 \\
0.75\end{array}$ \\
\hline & Sig. bet. periods & \multicolumn{3}{|l|}{$\mathrm{p}_{1}=0.025^{*}, \mathrm{p}_{2}=0.023^{*}, \mathrm{p}_{3}=0.025^{*}$} \\
\hline \multirow{4}{*}{ 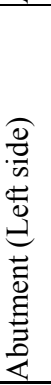 } & $\begin{array}{l}\text { Mesial to the saddle (No.3) } \\
\text { Min. - Max. } \\
\text { Mean } \pm \text { SD. } \\
\text { Median }\end{array}$ & $\begin{array}{l}0.50-0.75 \\
0.63 \pm 0.14 \\
0.63\end{array}$ & $\begin{array}{l}0.50-1.0 \\
0.75 \pm 0.16 \\
0.75\end{array}$ & $\begin{array}{l}0.50-1.0 \\
0.75 \pm 0.16 \\
0.75\end{array}$ \\
\hline & Sig. bet. periods & \multicolumn{3}{|l|}{$\mathrm{p}_{1}=0.180, \mathrm{p}_{2}=0.083, \mathrm{p}_{3}=1.000$} \\
\hline & $\begin{array}{l}\text { Distal to the saddle (No.4) } \\
\text { Min. }- \text { Max. } \\
\text { Mean } \pm \text { SD. } \\
\text { Median }\end{array}$ & $\begin{array}{l}0.25-0.75 \\
0.58 \pm 0.20 \\
0.63\end{array}$ & $\begin{array}{l}0.50-1.0 \\
0.79 \pm 0.19 \\
0.75\end{array}$ & $\begin{array}{l}0.75-1.0 \\
0.92 \pm 0.13 \\
1.0\end{array}$ \\
\hline & Sig. bet. periods & \multicolumn{3}{|l|}{$\mathrm{p}_{1}=0.025^{*}, \mathrm{p}_{2}=0.038^{*}, \mathrm{p}_{3}=0.083$} \\
\hline
\end{tabular}

$\mathrm{p}_{1}$ : $\mathrm{p}$ value for Wilcoxon signed ranks test for comparing between First reading and second reading

$\mathrm{p}_{2}$ : $\mathrm{p}$ value for Wilcoxon signed ranks test for comparing between First reading and third reading

$\mathrm{p}_{3}$ : $\mathrm{p}$ value for Wilcoxon signed ranks test for comparing between second reading and third reading

*: Statistically significant at $\mathrm{p} \leq 0.05$

because in particular it can fulfill various functions and influence the success of the RPD and its the intimate contact between metal connector and the palatal tissue, in addition to its wide mucosal coverage, enhances the support, retention and stability of the denture (19).

Those patients were selected with favorable oral health to ensure good health of abutment teeth, peridontium of the retained teeth and oral mucosa along the time of the study.

All patients were selected with acceptable maxillomandibular relationship and favorable occlusion to exclude any interference during mouth preparation and denture use, while patients with systemic disorders and oral diseases were excluded to avoid any damage to the denture foundation area $(20,21)$.

Patients with oral habits and occlusal discrepancy were also excluded from the study as these habits may interfere with the fit of RPD component and affect the occlusal surface of the retained teeth (22). Old age and smoking patients were excluded because these factors may affect denture foundation area as reported by many investigators $(23,24)$.

For laser sintered frameworks fabricated for our study, EOS cobalt chrome SP2 type was used, which is cobalt chrome, based metallic alloy powder for specially production of dental restoration in EOSINT M 270 system. EOS cobalt chrome SP2 powder is class IIa medical device directive 93/42/EES. Cobalt chrome SP2 powder is produced by gas atomization with particle size 45-100 microns and the chemical composition complies with type $4 \mathrm{CoCr}$ dental material in EN ISO 22674:2006 standard (25).

The patients were examined and evaluated for the following clinical parameters of periodontal tissues of the abutment teeth; plaque index (PI), Gingival index (GI), periodontal probing depth (PPD) and clinical attachment level (CAL) at the 3 different observation periods to evaluate the mucosal and periodontal health around the abutment teeth.
Plaque index and gingival index were selected to be applied in this study as they are considered perfect parameter for the favorable oral tissue health among removable partial denture wearers as recommended by Loe and Sillness $(14,15)$. Also periodontal probing depth was chosen for evaluation as it is more simple and applicable for all surfaces of teeth abutment. The clinical attachment level (CAL) was performed as the papilla on the proximogingival surface of the abutment tooth may be enlarged by a poor-fitting removable partial denture so, the clinical attachment level differentiate between enlargement of the gingiva and loss of attachment (16).

All over the follow up periods, it was observed that the gingival index showed no signs of any inflammatory reaction on gingival tissues both clinically, this result can be related to the more accuracy of the removable partial dentures fabricated by (CAD/CAM) technology and selective laser sintering technique. This accuracy was previously found by the study of Elmougy A. (26), who reported apparent accurate fit of all components of removable partial dentures fabricated by (CAD/CAM/SLS) technology.

The same result of accurate fit of the chrome cobalt frame work was reported by Williams et al. (3-27)Also it has been reported that the fit of removable partial denture frameworks produced using the additive manufacturing procedure is favorable comparable to frameworks produced using conventional methods.

Also there is another explanation for the absence of gingival inflammation in our study, which is related to the special type of Cobalt Chromium (SP2) powder, that used in for fabrication of SLS removable partial dentures in this regard, Danimir jevermovic et al. (28), that this type of Chrome Cobalt alloy which routinely used in all technologies such as SLM does not exhibit cytotoxic potentials. 
For plaque index there was significant increase of the plaque accumulation after all follow up periods and become significant at six months of denture use when compared with that of 3 months and at time of insertion, but it was noted that in spite of the significant increase of the plaque index all over this study periods, all the scores recorded were less than score 1 which is the least score value falling within the best oral health values as recommended by Loe and Sillness(14).

These low scores of plaque index can be related to the effective design and technique of fabrication (SLS) with high accurate fit which helps in reduction of plaque accumulation $(3-26,27)$.

This accurate fit helps in reduction of the plaque accumulation which affects the peridontium health by reducing bacterial population and consequently gives low scores of the clinical attachment and periodontal probing depth $(29,30)$.

The same little affection of the periodontal health and small numbers of carious lesions on abutment teeth was also reported by a study on 28 patients wearing removable partial denture for six year follow up period but under careful oral hygiene measures and periodontal treatment (31).

On the other hand some others reported that wearing of most types of conventional removable partial dentures result in high significant plaque index, gingival index, periodontal probing depth and loss of attachment which could be related to type of Chrome Cobalt alloy, less accurate fit and less effective design (32).

Likewise, other investigators attributed the reduced periodontal effect which was noted in patients wearing accurate denture design, to the effect of the accurate design to maintain a healthy oral environment and provide good oral hygiene (33). This attribution supports our results of reduced periodontal effects and higher oral health scores.

While conventional removable partial denture wearing lead to increased plaque accumulation on those areas of teeth and soft tissues which are covered by large areas of denture components (34), the use of CAD/CAM technology special laser sintering technique and using special type of Chrome Cobalt powder enhanced all oral hygiene parameters. Using $\mathrm{CAD} / \mathrm{CAM}$ technologies can produce finished parts from metal which may require a little standard finishing bead compared with conventional method. This supports our results of reduced inflammatory measures during all study periods due to highly polished dentures components which will help in reduction of plaque accumulation and inflammation production.

At the same time, manufacturing process and using fine powder particle size of EOS Cobalt Chrome SP2 produce fine grain structure compared to the cast structure have high strength which in turn helps in more accurate fit of the removable partial denture produced from that alloy (35) and this finding can explain the favorable clinical behaviors of wearing removable partial denture in our study.

At the same time, the laser mate RPDs was more hygienic and more biologically acceptable to the soft and hard tissues in the oral cavity when compared with conventional fabricated RPDs (36).

The absence of inflammatory cells among the epithelial desquamated cells seen in all of the observation period confirms the patients' choice criteria of good oral hygiene. The appearance of inflammatory cells reflects their presence in the underlying connective tissue and their exiting from the exopholiations then their movements toward and through the epithelium which desquamates in the oral cavity (37).

At the first observation period the prevailing of nonkeratinized epithelium may reflect a state of less mechanical stresses falling on the areas of denture construction or nonuse region. The absence of these inflammatory cells does not only reflect the healthy condition of the underlying connective tissue, but also the adjacent bone which might be influenced by the inflammatory mediators and undergoes resorption (38).

In the cytological smears obtained after 3 months, it was noted that the epithelial type seen in association with the exception patient change to contain in all patient changed to a degree of better maturation that is reflected in predominance of the cornified type of the epithelium. This is thought to reflect tissue response to the increase stimulating mechanical forces on the denture and homogenous distribution of the forces to the underlying tissues.

These findings supported by Marcovs',(39) who stated that the basic biochemical principle of good denture construction is conductive to better keratinization of soft tissues under dentures.

These finding in the present study are supported by Jani and Bhargava (40) who reported that three months period is enough to increase keratinized layer.

The absolute complete maturation of the desquamated epithelial cells in the swabs of the six months observation period reflect the patient adaptation to the new denture which provide that the oral environment well accept the new denture which in turn gained the normal epithelial keratinization characteristic of bearing areas with final typical epithelial maturation to orthokeratinization.

\section{CONCLUSIONS}

1. Wearing of chrome cobalt removable partial denture designed and fabricated by laser sintering rapid prototyping technique created favorable oral environment.

2. RPD designed and fabricated by CAD/SLS technology achieved accurate fit and adaptation to oral tissues and this has been reflected clinically and confirmed cytologically.

3. Clinically, wearing this RPD did not cause any discomfort to the patients, gingival inflammation or

4. bleeding, periodontal tissue damage or attachment loss or even plaque accumulation.

5. Cytologically, at the microscopic level, no inflammatory cells could be traced among the normally desquamated oral epithelial cells in the smears obtained.

6. There was obvious correlation between the great response of oral tissues and the technique used for manufacturing of the removable partial denture.

\section{CONFLICT OF INTEREST}

The authors declare that they have no conflicts of interest. 


\section{REFERENCES}

1. Abbas A, Nikzad S. The evaluation of rapid prototyping in dentistry: a review. Rapid Prototyping J 2009; 15: 216-25.

2. Miyazaki T, Hotta Y, Kunii J, Kuriama S, Tamaki Y. A review of dental CAD/CAM current status and future perspectives from 20 years of experience. Dent Mater J 2009; 28: 44-56.

3. Williams RJ, Bibb R, Eggbeer D, Collis J. Use of CAD/CAM technology to fabricate a removable partial denture framework. J Prosthet Dent 2006; 96: 96-9.

4. Hughes CW, Page K, Bibb R, Taylor J, Revington P. The custom-made titanium orbital floor prosthesis in reconstruction for orbital floor fractures. $\mathrm{Br}$ Oral Maxillofac Surg 2003; 41: 50-3.

5. Kanazawa M, Inokoshi M, Minakuchi S, Ohbayashi $\mathrm{N}$. Trial of a $\mathrm{CAD} / \mathrm{CAM}$ system for fabricating complete dentures. Dent Mater J 2011; 30: 93-6.

6. Rantanen T, Eerikanien E. Accuracy of the palatal plate of removable partial dentures, and influence of laboratory handling of the investement on accuracy. Dent Mater 1986; 2: 28-31.

7. Firtell DN, Muncheryon AM, Green AJ. Laboratory accuracy in casting removable partial denture frameworks. Prothet Dent 1985; 54: 856-62.

8. Barsby MJ, Schward WD. The qualitative assessment of Cobalt-Chromium Casting for partial dentures. $\mathrm{Br}$ Dent J 1989; 166: 211-6.

9. Romero GG, Engelmeier R, Powers JM, Canterbury AA. Accuracy of three corrective techniques for implant bar fabrication. J Prosthet Dent. 2000; 84: 602-7.

10. Gao B, Wu J, Zhao X, Tan H. Fabricating titanium denture base plate by laser rapid forming. Rapid Prototyping J 2009; 15: 133-6.

11. Pupo Y, Delgado J, Sereno L, Ciurana J. Scanning space analysis in Selective Laser Melting for CoCrmo powder. Procedia Eng 2013; 63: 370-8.

12. Eggbeer D, Bibb R, Williams R. The computer-aided design and rapid prototyping fabrication of removable partial denture frameworks. Proc Inst Mech Eng H 2005; 219: 195-202.

13. Martinez E, Amato K, Hernandez J, Ramirez DA, Wicker RB. Fabrication of metal and alloy components by additive manufacturing: examples of 3D materials science. J Mater Res Technol 2012; 1: 24-54.

14. Silness J, Loe H. Peridontal diseases in pregnancy. Acta Odonta Scand 1964; 22: 121-35.

15. Loe H, Silness J. Peridontal disease in pregnancy I. Prevalence and severity. Acta Odonta Scand 1963; 21: 522-51.

16. Glavind L, Loe H. Errors in the clinical assessment of periodontal destruction. J Peridont Res 1967; 2: 1808.

17. Drury RA, Wallington EA. Carltons Histological technique. $5^{\text {th }}$ ed. New York, USA: Ch Oxford University Press; 1980. p 335.

18. Kotz S, Balakrishnan N, Read CB, Vidakovic B. Encyclopedia of statistical sciences. $2^{\text {nd }}$ ed. Hoboken, N.J.: Wiley-Interscience; 2006.

19. Diwan R, Talic Y, Omar N, Sadig W. The effect of storage time of removable partial denture wax pattern on the accuracy of fit of the cast framework. J Prosthet Dent 1997; 77: 375-81.

20. Mayank A, Agrawal S, Agrawal S. Effects of systemic diseases on oral health. 2014; 3: 5-10. Available at: www. journalofdentofacialsciences.com

21. Preshaw PM, Walls AW, Jakubovics NS, Moynihan PJ, Jepson NJ, Loewy Z. Association of removable partial denture use with oral and systemic health. $\mathrm{J}$ Dent 2011; 39: 711-9.

22. Frank RP, Brudvik JS, Leroux B, Milgrom P, Hawkins N. Relationship between the standards of removable partial denture construction, clinical acceptability, and patient satisfaction J Prosthet Dent 2000; 83: 521-7.

23. Hummel SK, Wilson MA, Marker VA, Nunn ME. Quality of removable partial dentures worn by the adult U.S. population. J Prosthet Dent 2002; 88: 3743.

24. MacKntee M I. Measuring the impact of oral health in old age: a qualitative reaction to some quantitative views. Gerodontology 1996; 13: 76-81.

25. EOS, 2013. EOS system data sheet EOS P 396. Available at: http://www.eos.info/systems_solutions/plastic/system s_equipment/eos_p_396.

26. Elmougy AH. Evaluation of metallic removable partial denture framework fabricated by two different prototyping techniques. M.Sc. Thesis. Department of Removable Prothodontics, Faculty of Dentistry, Alexandria University. 2015.

27. Williams $R$, Bibb R, Rafik $T$. A technique for fabricating patterns for removable partial denture frameworks using digitized casts and electronic surveying. J Prosthet Dent. 2004; 91: 85-8.

28. Jevremovic DP, Puskar TM, Budak I, Vukelic D, Kojic V, Eggbeer D, Williams RJ. An RE/RM approach to thedesign and manufacture of removable partial dentures with a biocompatibility analysis of the F75 Co-Cr SLM alloy. Mater Tehnol 2012; 46: 123-9.

29. Fouad SA, Clinical and radiographic evaluation of residual ridge resorption under rigid and flexible immediate dentures. M.Sc. Thesis. Department of Removable Prothodontics, Faculty of Dentistry, Alexandria University. 2012.

30. Ardelean L, Bortun C, Podariu AC, Rusu LC. Some alternatives for classic thermopolymerisable acrylic dentures. Material Plastice 2012; 49: 30-3.

31. Bergman B, Hugoson A, Olsson CO. Caries, peridontal and prosthetic finding in patients with removable partial dentures: a six years longitudinal study. J Prosthet Dent 1982; 48: 506-14.

32. Yousof Z-Isa Z. Peridontal status of teeth in contact with denture in removable partial denture wearers. $\mathrm{J}$ Oral Rehabil 1994; 21: 77-86.

33. Chandler JA, Brudrik JS. Clinical evaluation of patients eight to nine years after placement of removable partial dentures. J Prosthet Dent 1984; 51: 736-43.

34. Watson IB, Mac Donald RD. Oral mucosa and complete dentures. J Prosthet Dent 1982; 47: 133-40.

35. Murr LE, Quinones SA, Gaytan SM, Lopez MI, Rodela A, Martinez EY, et al. Microstructure and mechanical behavior of Ti-6A1-4V produced by rapid-layer manufacturing, for biomedical 
applications. J Mech Behav Biomed Mater 2009; 2: 20-32.

36. Rekaby E, Metwaly A. Biological evaluation of abutment teeth for a new laser designed and finished RPD framework. Cairo Dent J 2012; 28: 1099-106.

37. Garant PR. Oral cells and tissues. London: Quintenence Books, 2003.

38. Nancy, A .Ten Cate, A. R. 2013 Oral histology development, structure and function. $8^{\text {th }}$ ed. St Louis: Mosby Company.

39. Markov NJ. Cytologic study of keratinization under complete dentures. J Prosthet Dent 1968; 20: 8-13.

40. Jani RM, Bhargava KA. Histologic comparison of mucosa before and after wearing complete dentures. J Prosthet Dent 1976; 36: 254-60. 